\title{
Tetraplex Pcr Reveals Aspergillus Welwitschiae Incidence in Onion Bulbs.
}

\author{
Fernanda Pelisson Massi (I), Karla Murata Vieira (I), Beatriz Thie \\ lamanaka (II), Marta Hiromi Taniwaki (II), Maria Helena Pelegrinelli \\ Fungaro (I) \\ (I) UEL - Universidade Estadual de Londrina (CCB, Campus Universitário, Rodovia Celso \\ Garcia Cid, Km 380), (II) ITAL - Instituto de Tecnologia de Alimentos (Av Brasil 2880, \\ Campinas, SP)
}

\section{Resumo}

Aspergillus section Nigri are widely distributed fungi in nature, as well as are often found in foods. Currently, 28 species are recognized in this section but differences between them are often subtle requiring the combination of molecular and morphological methods for their identification. Some species are known as toxin producers, including ochratoxins and fumonisins. In Brazil, Aspergillus seção Nigri has been found in onions, but its contribution for increasing the consumption of ochratoxins and fumonisins is unknown. We aim to examine the incidence of Aspergillus niger sensu stricto and A. welwitschiae in onion bulbs (Allium cepa) commercialized in Paraná State (Brazil), and determine the possible occurrence of strains harboring ochratoxin and and fumonisin genes. Pieces of skins from the outer and inner side of the bulb scale as pieces of roots from 23 onion samples, collected monthly, were treated with $0.4 \% \mathrm{NaOCl}$ for $2 \mathrm{~min}$, plated in DG18 medium and incubated $\left(25^{\circ} \mathrm{C}\right.$ for 7 days). All isolates were analyzed by means of a tetraplex polymerase chain reaction to simultaneously detect: A. niger/A. welwitschiae species, the presence of the R-oxoamine synthase (An01g06870) gene, essential for fumonisin biosynthesis, FAD-binding oxidoreductase (An15g07880) and polyketide synthase (An15g07920), both essential for ochratoxin biosynthesis. The frequency of Aspergillus section Nigri species in skins from the outer and inner side of the bulb scale was $37.9 \%$ and $54.1 \%$,

\footnotetext{
Referência:

Fernanda Pelisson Massi, Karla Murata Vieira, Beatriz Thie lamanaka, Marta Hiromi Taniwaki, Maria Helena Pelegrinelli Fungaro.Tetraplex Pcr Reveals Aspergillus Welwitschiae Incidence in Onion Bulbs.. In: Anais do 12ㅇ Congresso Latinoamericano de Microbiologia e Higiene de Alimentos - MICROAL 2014 [= Blucher Food Science Proceedings, num.1, vol.1]. São Paulo: Editora Blucher, 2014. 
respectively; in roots the occurrence was $39.1 \%$. Approximately $92 \%$ of the isolates belong to $\mathrm{A}$. welwitschiae and $8 \%$ to $\mathrm{A}$. niger and isolates varied relative to the presence of genes involved in mycotoxin biosynthesis. The gene encoding R-oxoamine synthase was found in $40 \%$ of the isolates, but only $10 \%$ were found to have FAD-binding oxidoreductase and polyketide synthase encoding genes. Concluding, A. welwitschiae is the most frequent species in onions and about half of the isolates have genes encoding key enzymes involved in toxin biosynthesis. The investigation on the A. welwitschiae ability to produce fumonisins and ochratoxin in onions is a predominant need.

Palavras-Chave: Aspergillus, fumonisin, ochratoxin, onion Agência de Fomento: FAPESP, CNPQ, Fundação Araucaria 